\title{
JOURNAL.RU
}

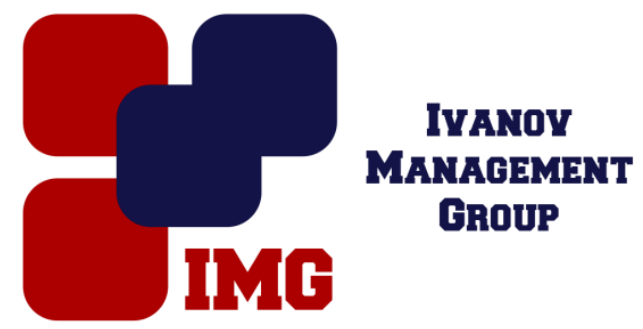

Урунов А.А.

ФГБОУ «Государственный университет управления»

Москва, Россия

doi: $10.18411 / 1 \mathrm{j}-31-07-2017-50$

idsp 000001:1j-31-07-2017-50

\section{Экономический рост или благополучие отдельных групп}

Сегодня нельзя представить экономическое развитие без учета условий социальной жизнедеятельности людей, а также экологической безопасности региона. В рыночной экономике имеет место несовпадение интересов производителей с экологической обстановкой отдельных местностей, где проживают люди, а также на фирмах наблюдается жестокая эксплуатация собственником наемной силы. Движущим стимулом развития капиталистического производства является погоня за максимальной прибылью. Только стремление к прибыли, личной наживе руководит деятельностью владельцев фирм и компаний. Высокий уровень выпуска материальных благ при неблагополучной экологии и низком уровне социальной защиты людей - вряд ли оправдает и правомерен, даже при обеспечении полной занятости.

Прибыль как экономическая категория в будущем не только определяет прогресс отдельного индивида, фирмы, общества, или мира в целом, но с таким же успехом приближает человечества к самоуничтожению. Известно, что прибыль еще не означает экономический рост. Наш мир сильно стал зависимым от прибыли, и именно она определяет судьбу цивилизации, нежели другие факторы (внушающие ядерные арсеналы или отдельный террорист-камикадзе, инопланетяне). Все больше устойчивую силу воздействия получает различие интересов группы людей от интересов общество в целом. Все большее удаляет этих интересов воздействия мощного потока торгового капитала. Торговый капитал в своем пути сметает мелких производителей товаров и услуг, и 
отдельных фирм. Разочарование мелких предпринимателей все больше проявляются в связи с их неспособностью получать прибыли от незначительного запаса капитала в своем обороте, и усиливается боязнь не попасть в «социальное дно». Кстати, именно это группа людей, как представители среднего слоя, больше склонны, существенно влиять на экономический рост.

Спустя 25 лет с начало реформ, трудно описать истинную картину социально-экономической жизни в обществе. Можно сказать, завершилась поляризация общества на все возможные слои. Обычно социальное общество в классическом варианте капитализма в зависимости от удельного веса населения подразделяются на людей среднего достатка (средний слой), на людей высшего класса («будущее новой нации»), интеллигенцию, чиновников и служащих, бедных (малоимущие) и лиц без определенного местожительства (бомж), другими словами последний составляют «социальное дно»[1]. Ниже попытаемся в приблизительном варианте представить современную структуру российского общества.

По нашим расчетам по состоянию на начало 2017 года удельный вес людей среднего достатка составляет 27,5\% населения России. Принято считать, что показатель здорового общества является высокий удельный вес средних слоев населения к общему итогу. Мировая практика показывает, именно они могут сгладить в большинстве случаев социальные трения или напряженности в обществе. Основным достоинством этого слоя является то, что, голосуя своими сбережениями, они позволяют работать своим ресурсам на пользу общества и государства. Многие члены этого слоя даже не подозревают об этом, ими движет только их собственные интересы. Для того, чтобы ими двигали интересы, государство должно создать все предпосылки для этого. Жизнь показывает, что средний слой идёт на создание собственного дела в форме малого или среднего бизнеса и, без всякого сомнения, заинтересован в экономическом росте страны.

К сожалению, сегодня отношение между малым бизнесом и государством складываются нелегко и не защищен от иностранных конкурентов, столь же беспомощен он и перед всемогуществом отечественных монополистов. Мало того, органы власти различных уровней возводят на пути мелкого предпринимательства административные барьеры, усложняя процедуру и завышая стоимость регистрации малых предприятий. Отечественные бизнесмены с 
трудом пробираются сквозь систему лицензирования и состоят под неустанным контролем многочисленных, дублирующих друг друга органов.

У большинство, судя по опыту, складывается впечатление, что для успешной работы малого бизнеса необходимы хорошие личные взаимоотношения с властями, особенно с конкретными чиновниками, отвечающими за тот или иной участок работы. Русская поговорка «не имей сто рублей, а имей сто друзей» нынче в моде по-другому «не имей сто рублей, а имей сто связей». Предприниматели признают, что стараются избежать любых конфликтов с органами власти, ибо существует множество административных рычагов, позволяющих «прижать» неугодную фирму. Наши и исследования других[1,2] свидетельствует, что пятая часть опрошенных считают, что региональные власти не отказывают в помощи никому, кто за ней обращается; $18 \%$ руководителей утверждали, что власти помогают только «своим» фирмам, а $15 \%$ заявило, что помощи сверху не получает никто.

Люди высшего слоя (класса), так называемые «представители будущей новой нации», другими словами «новые нации» имеют ограниченный круг общения предпочтительно среди своих и иностранных граждан за пределы страны. Обычно в состав и структуры этого слоя общества входят видные партийные и государственные чиновники или бывшие, собственники крупных банков и финансовые магнаты, а также владельцы узловых предприятий российской экономики, действующих, прежде всего на добывающих отраслях. К ним более или мене примыкают $10 \%$ обслуживающего их слоя: директора и менеджеры. К высшему слою также входят знаменитые артисты, врачи, спортсмены и другие.

Удельный вес высшего класса (элиты) России примерно составляет 5-6\%. Этому классу людей характерно масштабно мыслить и по желанию инвестировать свой капитал на крупные проекты, что в отечественную экономику и что за ее пределами. Ими оборачивается крупные финансы, и ее суммарный объем примерно составляет 75\% годовой ВВП. Этим людям не понять жизнь простого россиянина, как, например, того же самого, пенсионера, всю жизнь строившего метрополитен г. Москвы, а теперь месяцами живущего не зная мясо. Необходимо отметить, что «социальное дно» в некоторых случаях готово поглотить и уже поглощает инженерно-технических работников, учителей, творческую интеллигенцию, ученых.

Ученые в российском обществе живут по-особому. Они проводят активность то среди своих, то среди высшего слоя, чиновников среднего и 
высшего ранга. У большинство их творческая деятельность стало малопродуктивным по сравнению с советским периодом. Это объясняется следующими моментами. Во-первых, отсутствием необходимых средств на науку у государства. Во-вторых, изменение целевых установок государства в сторону так называемых элитных и отраслевых вузов и научных сотрудников. Втретьих, большим оттоком высококвалифицированных кадров из сферы науки в другие отрасли, утечки мозгов за рубеж вследствие низкого уровня оплаты труда.

Служащие (чиновники), находящиеся у власти проявляют свою активность исключительно среди политиков, а временами, если это возможно среди простого народа (в период выборов). В большинстве своем хронически у них не хватает минимума знаний на занимаемую должность, так как сейчас кадры назначаются или выбираются (модно, командами). Судя по тому, как большинство чиновников ведут себя в обществе после повышения их социального статуса, невольно замечаешь интересную«закономерность» - с повышением должности в иерархии государственного управления якобы пропорционально растет у чиновника ум и знание, и соответственно те требуют к себе большего уважения. Однако это иллюзия наших дней.

Бедность и ее рост является центральной проблемой современного общества. Бедность в России является многомерным явлением, и возникли в две формы: «застойная» и «плавающая». Первая форма выражается в последовательном продолжении бедности из одного в другое поколение с рождения. Бедность, определяемая уровнем дохода и потребления, выражается в нехватке продуктов питания, одежды, недостаточной уровни реальной заработной платы, низких пенсиях, нехватке земли и домашнего скота в сельских местах и т.п. Бедные родители воспроизводят потенциально бедных детей, что предопределяется их здоровьем, образованием, квалификацией и др.

Уровень бедности классифицируется в специальной литературе как низкая, средняя, высокая и очень высокая. Согласно этой классификации Россия находиться среди стран группы высокого уровня, где по нашим расчетам более 58\% населения проживают ниже отметки общепринятых стандартов жизни. По определению самих людей более 60\% населения считают себя бедными. Бедность приводит к заметному сокращению среднедушевого уровня потребления основных продуктов питания. Так, в России потребление мяса и мясопродуктов в 2015 г. составило 47 кг против 69 кг в 1991 г., молока и молокопродуктов в 2015 г. соответственно, 227 кг против 347 кг. [3]. Основная 
масса населения в странах СНГ вынуждена тратить практически все свои доходы только на продукты питания. Причинами появления и роста новых «бедных» автор видит в следующем. Первое - безработица, вследствие спада производства и мировых кризисов. Второе - большинство населения, включая пенсионеров, инвалидов, и лиц не способных умело использовать сбережения, лишились в свое время своих сбережений. Третье - это вынужденное переселения людей всеми семьями из обжитых мест в более благополучные регионы, вследствие нестабильной политической обстановки.

Малоимущие или люди без определенного место жительства в современных понятиях в нашем обществе это не те люди, которые при социализме считались паразитами и дебоширами, хотя может и за. К сожалению, большая часть этой социальной группы людей, а их по разным подсчетам в России составляет около 1,5 миллионов человек, скорее это продукт не продуманной, неправильной политики неравенства доходов, следствие безработицы продолжительностью более одного года и других подобных факторов. Разумеется, люди, решившие на такой образ жизни отчасти не от хорошей и благополучной условии проживание, а от безысходности и отсутствия перспективы. Человек не может жить без целей, идеалов, веры, надежд и т.д.

Таким образом, нами представлена эмпирическо-априорная картина современной структуры социально-экономической жизни России, от которой зависит динамика экономического роста страны. Совершенно очевидно, что выделенные выше нами социальные слои общества различаются не только уровнем материальной обеспеченности, но у них разная система ценностей и приоритетов, разные предпочтения и потребительский $\quad$ спрос, они приходят на разные потребительские рынки, отличающиеся не только набором товаров и услуг, но и ценами на аналогичные потребительские блага. Для них характерны разные мотивации, нормы и стереотипы общественного поведения. Без преувеличения утверждаем, что различные слои общества или другим выражением - «две России», с трудом понимают друг друга и говорят на разных языках. Сегодня совершенно не существует подобного понимания общества по интересам, как это было 25 лет тому назад. 
1. Российские средние слои накануне и на пике экономического роста. - М.: Экон-Информ, 2008. - 200 c.

2. Средние слои в России. Экономические и социальные стратегии / По; ред. Малеевой Т.М. М.: Гендальф, 2003. - 506с.

3. Урунов А.А. Единое экономическое пространство [Текст]: монография / А. А. Урунов. М.: Синергия, 2012. - 383 с. 